\title{
Employee Transfer, Work Motivation and Employee Performance
}

\author{
Muhammad Alkirom Wildan \\ Management Department, Faculty of Economics and Business, University of Trunojoyo Madura, \\ Bangkalan, Jawa Timur, Indonesia \\ E mail: wildan.alkirom69@trunojoyo.ac.id
}

\begin{abstract}
This study was pointed to decide: employees' transfer, work inspiration, performance, the impact of representatives transfer on the performance; work inspiration towards the performance; workers transfer and work inspiration towards the employees' performance of BPK Representative of Jawa Timur Province. This investigate employments quantitative approach with clear affiliated inquire about. The information examination method utilized in this considers is path analysis. The comes about of this ponder demonstrate that: recognition of workers transfers in BPK Representative of Jawa Timur province is moo, the work inspiration of representatives is exceptionally sufficient, the performance is sufficient, workers transfer isn't noteworthy to workers performance. The conclusion from this study is that employees' exchange doesn't have noteworthy impact on employees' performance somewhat. Work inspiration has positive and noteworthy impact on employees' performance. Workers exchange and work inspiration together have a critical commitment on representatives performance.
\end{abstract}

Keywords - Employee Transfer; Motivation; Performance.

\section{Introduction}

Performance is the result of work or contribution achieved by an individual in achieving organizational goals in accordance with their duties and obligations. There are two criteria in measuring the contribution of individual to the organization, namely based on the evaluation of the work results and based on the work behavior, Gomes in Prasetya (2018). Based on the evaluation of the work results, it isknownthatduring2016until2018 the Audit Board of the Jawa Timur Provincial Representative Has not been able to achieve the overall main performance indicators planned to the maximum, namely the percentage of follow-up completion of the recommendations of the examination results. In addition, the results of the evaluation of work behavior are known that employees have a fairly high absenteeism rate.

One of the factors that affect employee performance is employee motivation. Motivation is closely related to the behavior shown by employees in carrying out their daily duties. Motivation is the provision of power to move and create enthusiasm of an employee so that they want to work and want to work together effectively and integrated, so that a satisfactory result is obtained, Hasibuan (2016).

Another factor that can affect employee performance is employee transfer. According to Siagian in Dewi (2017) Mutasi serves to provide new experiences, expand employee knowledge and skills, avoid saturation, to fill existing vacancies, and increase employee motivation. While according to Hasibuan (2016) the objectives of implementing transfers between lain are: increase productivity, put people in the right position, increase employee knowledge, encourage career planning, and create a balance of organizational structure.

Employee transfer has a huge benefit both to the organization and to the employee itself. In the environment of the Audit Board of Finance transfer for examiners is necessary to maintain the independence owned by employees.

In other contents, there are psychological problems that must be faced by employees related to the implementation of employee transfers. Budiman (2018) stated that problems in employee transfer can be distinguished in to two types, namely work-related problems and problems that are not related to work. Workrelated issues such as adaptation to the new environment and responsibilities. While the problems that are not related to work for example are decisions about exitga, new residence, social and emotional stress, and so on.

Problems both related to work and not, if not handled properly can affect the overall performance of the organization. Mignonac in Budiman (2018) states that unwanted transfers by employees can lead to decreased performance, resistance, and decreased work quality. In short there can be a decreased behavior of ability to work even the desire to stop working.

The issue of employee transfer in BPK RI employee environment, especially in the Representative of Jawa Timur Province is a problem that is often discussed by employees. This is because most of BPK Jawa Timur employees are overseas employees who live separately with their families. All BPK Jawa Timur employees of 
course want to gather and live with family. One of the expectations for employees to be able to gather with family is the certainty about the pattern of transfer so that employees can determine the long-term plan for the display for their families.

One of the parameters to assess motivation is through the discipline of employees indicated by their absence. At the Audit Board of The Jawa Timur Provincial Representative, the level of employee attendance throughout 2017 to 2018 is known that the average attendance rate of BPK Representative of Jawa Timur Province is 7.14. Hasibuan (2016) stated that absenteeism is the absence of employees within the organization for certain reasons. If the attendance rate of employees in an organization has reached above $5.7 \%$ then it is considered to exceed the limits of fairness so it needs to be taken into care by management. It known that many employees do not comply with the existing regulations. Some employees enter the office with clothes that do not comply with the uniform and do not wear shoes, IDs, or proper work clothes as required in the applicable regulations.

In addition, many employees who enter the office just to do electronic presence, rest outside recess, and leave the workplace for no apparent reason especially if the boss of the pegawai is not in place. The average employee delay is quite high which is 0.41 hours per month. Based on the description above, further research is needed on whether this is an indicator of low motivation and performance of employees at BPK Representative of Jawa Timur Province.

The condition of motivation and employee transfer will ultimately boil down to the performance of the organization. Based on the data of the Performance Accountability Report of BPK Representative of Jawa Timur Province, it is known that there is one of the main performance indicators of the organization that is always not achieved from year to year, namely the percentage of follow-up completion of the recommendations of the inspection results. This suggests that there is a gap between the ideal performance conditions expected by the organization and the actual conditions.

\section{Literature and Hypothesis Studies}

\subsection{Human Resource Management}

According to Mondy, Wayne R., in Panggabean (2016) Human Resource Management (MSDM) is the utilization of human resources /employees in order to achieve the goals that have been fixed by the organization. In addition, Nickson, Dennis in Panggabean (2016) stated that MSD Misan effort made by the organization to manage human resources in order to achieve the goals of the organization. Next up is Daft, Richard L. in Panggabean (2016) suggests that MSD Mis the implementation of management functions effectively and efficiently to achieve organizational goals.

\subsection{Employee Transfer}

According to Hasibuan (2016)employee transfer is one of the tasks of employee development carried out by moving or changing the position of employees both vertically and horizontally within an organization. Santoso in Dewi (2017) stated that transfer is the transfer of employees from the excess energy part to the part that requires energy.

\subsection{Work Motivation}

Hasibuan (2016) stated that motivation is a driving effort to mobilize and create the spirit and passion of pegawai to be willing to work and work to get the effectively and synergistically so as to obtain maximum results. Furthermore Mangkunegara (2017) stated that motivation is seen from one's attitude to an organization in dealing with work situations. From the various definitions that have been mentioned can be concluded that motivation is the thrust that causes an employee to exert all the ability to carry out the obligations and tasks given so that the desired goals can be achieved.

\subsection{Employee Performance}

Sutrisno (2016) stated, performance is the result of the work of employee in an organization that is carried out in accordance with the obligations and responsibilities charged to him to achieve a certain goal. According to Mathis and Jackson in Princess (2016) performance is the things that an employee does or does not in carrying out its work. According to Samsudin in Putri (2016) performance is output or the work of employees both as a group and individually in an organization. Based on various definitions, it can be concluded that performance is the result of work achieved by an employee in accordance with the duties and duties of his tires to achieve organizational goals.

\subsection{Hypothesis Development}

The results of the study conducted by Putri (2016) stated that there is a very strong relationship between employee transfer and the performance of operational employees at Vio Cihampel as Bandung Hotel. Wutsqo research results (2017) also showed similar results. The result of the study is one of them is that employee transfers

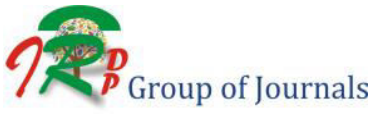


have a positive and significant effect on employee performance.

$H_{1}=$ Employee transfer $\left(X_{1)}\right.$ has a significant effect on employee performance $(Y)$

The results of Dewi's research(2017)stated that there is a significant influence between motivation variables and performance variables.

$\mathrm{H}_{2}=$ Work motivation $\left(X_{2}\right)$ has a significant impact on employee performance $(Y)$

The results of research conducted by Dewi (2017). Based on the study it is known that there is a significant influence between transfer variables and motivation variables simultaneously on performance variables.

$H_{3}=$ Employee Transfer $\left(X_{1}\right)$ and motivation work $\left(X_{2}\right)$ Simultaneous Influential towards Performance official $(Y)$

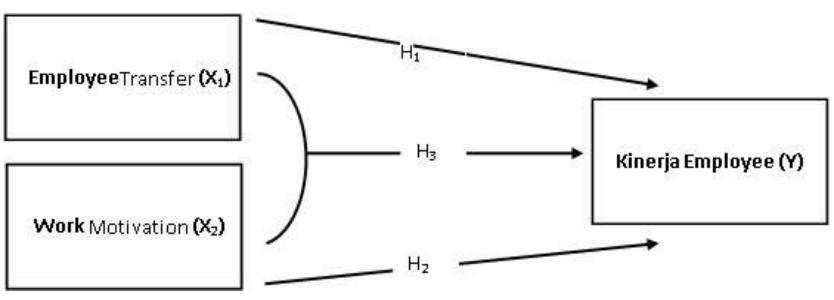

Fig. 1: Skeleton theoretical research

\section{Research Methods}

This research according to the level of explanation is descriptive and associative. Whereas according to the type of data and analysis conducted this research using

quantitative research approach. The data collection procedure is carried out through questionnaires as the main data source, and is supplemented by interviews/observations and document analysis. The research questionnaire was used to measure the level of employee perception of employee transfer variables, work motivation, and employee performance variables. Research questions are defined and derived from variable dimensions based on pre-existing theories. The questions in the research questionnaire tested their validity by product moment correlation method or also called Pearson test. The reliability of the research instrument was tested using the alpha coefficient method (alpha cronbach).

The research sample was 49 civil servants in BPK RI representative of Jawa Timur province. The dissemination of questionnaires was conducted using $e$-form to the entire population with the data of questionnaire results presented anonymously in this study.

The data analysis technique used in this study is path analysis. The path analysis method is equipped with a classic assumption test method to ensure that the data obtained is appropriate for analysis using the path anal method. The classic assumption tests conducted in this study are normality test, multicollinearity test, heteroscedasticity test, and linearity test.

\section{Results and Discussion}

Table 1. Respondent Characteristics by Age, Gender, Education Level, and Marital Status

\begin{tabular}{|c|c|c|c|c|c|c|c|c|c|c|c|}
\hline $\begin{array}{c}\text { Age } \\
\text { (years) }\end{array}$ & $\mathbf{F}$ & $\%$ & Gender & $\mathbf{F}$ & $\%$ & Education Level & $\mathbf{F}$ & $\%$ & $\begin{array}{r}\text { Marital } \\
\text { Status }\end{array}$ & $\mathbf{F}$ & $\%$ \\
\hline $21-30$ & 34 & 70 & 1 & 27 & 55 & D3/Diploma & 6 & 12 & $\mathrm{M}$ & 27 & 55 \\
\hline $31-40$ & 11 & 22 & $\mathrm{~F}$ & 22 & 45 & S1/Undergrad & 36 & 74 & $\mathrm{D}$ & 22 & 45 \\
\hline $41-50$ & 4 & 8 & & & & S2/Postgrad & 7 & 14 & $\mathrm{~S}$ & & \\
\hline Total & 49 & & & 49 & & & 49 & & & 49 & \\
\hline
\end{tabular}

From Table 1 it is known that employees at BPK Representative of Jawa Timur province are dominated by employees with a productive age of $70 \%$ of employees between the ages of 21-30 years with an adequate level of education that is $74 \%$ with undergraduate education.

Table 2. Data Descriptive Statistics Research (Average Variable)

\begin{tabular}{|l|r|r|r|r|r|}
\hline & N & Minimum & Maximum & Mean & Std. Deviation \\
\hline Transfer $\left(\mathrm{X}_{1}\right)$ & 49 & 1,25 & 4,08 & 2,82 & 0,76 \\
\hline Work Motivation $\left(\mathrm{X}_{2}\right)$ & 49 & 1,70 & 5,00 & 4,11 & 0,89 \\
\hline Performance $(\mathrm{Y})$ & 49 & 1,00 & 5,00 & 3,87 & 0,86 \\
\hline Valid N & 49 & & & & \\
\hline
\end{tabular}


The average value of each variable compared to the Neuman scale range that has been set to assess the variable level is as follows: 4 - 5 is very good;3 - 4 is good;2 - 3 is not good; and 1 - 2 is not very good. From table 1 it is known that, the average respondent's answer to the transfer variable $\left(\mathrm{X}_{1}\right.$ ) shows a low value (mean value of 2.82 ) which indicates that the perception of transfers owned by employees in BPK Representative of Jawa Timur province is low. The average respondent's answer to the work motivation variable $\left(\mathrm{X}_{2}\right)$ showed excellent value (mean value of 4.12) which showed that the work motivation of employees at the Financial Examiner's Office of the Jawa Timur Province Representative was very high. While the average respondent's answer showed a good score (mean value of 3.87). This shows that the performance of employees at BPK Representative of Jawa Timur province is high.

Table 3. Transfer Instrument Validity and Reliability Test Results $\left(X_{1}\right)$, Work Motivation $\left(X_{2}\right)$, and Performance $(Y)$

\begin{tabular}{|c|c|c|c|c|c|r|r|r|}
\hline $\begin{array}{l}\text { Employ } \\
\text { ee } \\
\text { Transfe } \\
\mathbf{r}\end{array}$ & $\begin{array}{c}\text { Value } \\
\mathbf{r}\end{array}$ & $\begin{array}{c}\text { value } \\
\text { Cronbach's } \\
\text { Alpha }\end{array}$ & $\begin{array}{c}\text { Motovasi } \\
\text { Work }\end{array}$ & Value r & $\begin{array}{c}\text { value } \\
\text { Cronbach's } \\
\text { Alpha }\end{array}$ & $\begin{array}{c}\text { Employee } \\
\text { Performa } \\
\text { nce }\end{array}$ & $\begin{array}{c}\text { Value r } \\
\text { value } \\
\text { Cronbach's } \\
\text { Alpha }\end{array}$ \\
\hline $\mathrm{X}_{1.1}$ & 0,791 & 0,914 & $\mathrm{X}_{2.1}$ & 0,937 & 0,969 & $\mathrm{Y}_{1}$ & 0,912 & 0,970 \\
\hline $\mathrm{X}_{1.2}$ & 0,863 & 0,910 & $\mathrm{X}_{2.2}$ & 0,932 & 0,969 & $\mathrm{Y}_{2}$ & 0,943 & 0,969 \\
\hline $\mathrm{X}_{1.3}$ & 0,868 & 0,910 & $\mathrm{X}_{2.3}$ & 0,937 & 0,969 & $\mathrm{Y}_{3}$ & 0,894 & 0,971 \\
\hline $\mathrm{X}_{1.4}$ & 0,822 & 0,912 & $\mathrm{X}_{2.4}$ & 0,933 & 0,969 & $\mathrm{Y}_{4}$ & 0,963 & 0,969 \\
\hline $\mathrm{X}_{1.5}$ & 0,830 & 0,911 & $\mathrm{X}_{2.5}$ & 0,861 & 0,972 & $\mathrm{Y}_{5}$ & 0,894 & 0,971 \\
\hline $\mathrm{X}_{1.6}$ & 0,706 & 0,918 & $\mathrm{X}_{2.6}$ & 0,878 & 0,971 & $\mathrm{Y}_{6}$ & 0,842 & 0,973 \\
\hline $\mathrm{X}_{1.7}$ & 0,813 & 0,913 & $\mathrm{X}_{2.7}$ & 0,791 & 0,975 & $\mathrm{Y}_{7}$ & 0,873 & 0,972 \\
\hline $\mathrm{X}_{1.8}$ & 0,642 & 0,921 & $\mathrm{X}_{2.8}$ & 0,913 & 0,970 & $\mathrm{Y}_{8}$ & 0,914 & 0,970 \\
\hline $\mathrm{X}_{1.9}$ & 0,366 & 0,933 & $\mathrm{X}_{2.9}$ & 0,908 & 0,971 & $\mathrm{Y}_{9}$ & 0,840 & 0,973 \\
\hline $\mathrm{X}_{1.10}$ & 0,619 & 0,921 & $\mathrm{X}_{2.10}$ & 0,916 & 0,970 & $\mathrm{Y}_{10}$ & 0,831 & 0,973 \\
\hline $\mathrm{X}_{1.11}$ & 0,635 & 0,921 & & & & $\mathrm{Y}_{11}$ & 0,886 & 0,971 \\
\hline $\mathrm{X}_{1.12}$ & 0,881 & 0,910 & & & & & & \\
\hline
\end{tabular}

From table 3 it is known that the results of reliability tests show that all question items contained in the research instrument are valid and reliable i.e. because the value is above the $r$ table value and the $\alpha$ value so that it can be used in research.

Multilinearity test results showed that there was no multilinearity problem that could be seen from the VIF value for both independent variables less than 10 , and the Tolerance value of more than 0.100 . Heteroskedastic test results on scatterplot charts, it can be known that the points spread with an obscure pattern above and below the number 0 on the $\mathrm{Y}$ axis so that it can be concluded that there is no problem of heteroskedastic in the regression model. Langrange Multiplier linearity test results suggest that the value of $\mathrm{R}$ square $\left(\mathrm{R}^{2}\right)$ is 0.001 , with a calculated $\mathrm{c} 2$ value of 0.049 smaller from $c 2$ table $(0.049<62.830)$, it can be concluded that the linear model is right to use.

Table 4. t-test result

\begin{tabular}{|c|l|l|}
\hline Variable name & t & P-Value \\
\hline Transfer $(\mathrm{X} 1)$ & 0.994 & 0.000 \\
\hline Work Motivation $(\mathrm{X} 2)$ & 0.977 & 0.000 \\
\hline
\end{tabular}

Based on the calculation obtained linear regression equation as follows: $Y=8,570-0.994 X_{1}+0.977 X_{2}$

Test of transfer variable regression coefficient (X1) showed that the calculated $-\mathrm{t}$ value $>-\mathrm{t}$ table $(-1,642>-2,013)$ or $>$ significance of $0.05(0.107>0.05)$. This means that variable $\mathrm{X}_{1}$ has no partial effect on $\mathrm{Y}$. It can be concluded that,

$H_{1} a$ : employee transfer partially has a significant effect on employee performance, because it is not proven based on the results of partial t-test analysis.

The motivation variable regression coefficient test $\left(\mathrm{X}_{2}\right)$ shows that the calculated $\mathrm{t}$ value $>\mathrm{t}_{\text {table }}(16,554>2,013)$ or significance of $<0.05(0.000<0.05)$ means that the motivation of work in an arstial manner has a significant effect on employee performance. It can be concluded that,

$\mathrm{H}_{2} \mathrm{a}$ : partial work motivation has a significant effect on employee performance, because it is proven based on the results of partial t test analysis. 
Table 5. F Test Results ANOVA ${ }^{b}$

\begin{tabular}{|l|r|r|r|r|r|}
\hline \multicolumn{1}{|c|}{ type } & \multicolumn{1}{c|}{ Sum of Squares } & \multicolumn{1}{c|}{ Df } & Mean Square & \multicolumn{1}{c|}{ F } & \multicolumn{1}{c|}{ Sig. } \\
\hline Regression & 3712,916 & 2 & 1856,458 & 140,178 & $0.000^{\mathrm{a}}$ \\
\hline Residual & 609,206 & 46 & 13,244 & & \\
\hline Total & 4322,122 & 48 & & & \\
\hline
\end{tabular}

From Table 4.20 it is known that variables $X_{1}$ and $X_{2}$ together affect $\mathrm{Y}$ because the value of $\mathrm{F}$ calculates the table > $\mathrm{F}(140,178>3,200)$ or the significance of $<0.05(0.000<$ $0.05)$. It can be concluded that $\mathrm{H}_{3} \mathrm{a}$ is employee transfer and simultaneous work motivation of SECara has a significant effect on employee performance received because it is proven based on F Test analysis.

Table 6. Coefficient of Determination Value $\left(\mathbf{R}^{2}\right)$

\begin{tabular}{|c|c|}
\hline R-Square & Adjusted R Square \\
\hline 0.859 & 0.853 \\
\hline
\end{tabular}

Based on table 6 , it can be known that variables $\mathrm{X}_{1}$ and $\mathrm{X}_{2}$ together have an influence contribution to $\mathrm{Y}$ of 0.859 or $85.9 \%$. While the remaining $14.1 \%$ was influenced by other factors that were not studied.

\section{Discussion}

Hasibuan (2016) stated that one of the systems used as the basis for the implementation of employee transfer is the Merit System. Merit system is employee transfer system is done objectively based on scientific considerations, as well as by improving the work performance that has been achieved. Merit system is the best transfer system compared to seniority system and spoil system because it is the system that is considered the fairest and can spur performance improvement and employee productivity.

Provisions on transfers are stipulated in Government Regulation of the Republic of Indonesia Number 11 of 2017 concerning Civil Servant Management. In article 162 of the Government Regulation, it is stated that: "Career development, development of competence, career patterns, transfers, and promotions are civil servant career management that must be done by applying the principle of Merit System." Based on the results of descriptive analysis of data that has been done it is known that the transfer mechanism implemented in the environment of the Audit Board of Finance has not been entirely based on merit system. Responses from respondents related to the implementation of transfers indicate that the transfers carried out have not used scientific considerations and performance that have been achieved (Wildan, 2021).
Hamzah in Astuti (2017) states that the indices of work motivation can be grouped as internal motivation and external motivation. Internal motivation is a motivation that comes from within a person. This motivation cannot be changed by others (management or organization) except at the will of the person himself. External motivation is motivation that comes from outside or from one's environment. This motivation is commonly used by management to improve one's performance. The results of the data analysis obtained are known that the internal and external motivations owned by BPK Representative of employees of Jawa Timur are high.

Robbins in Sari (2015) suggests that performance can be measured through 6 indicators: commitment; selfreliance; effectiveness; punctuality; quantity; and quality. Based on the results of the data analysis conducted can be known that the commitment, independence, effectiveness, timeliness, quantity, and quality of work of BPK Employees Representing Jawa Timur is high. The first hypothesis of this study is that transfers have a significant effect on the performance of employees in BPK Representative of Jawa Timur Province. The effect of transfers on employee performance can be known in hypothesis tests. From the test results, it is known that transfers do not significantly affect the performance of employees in BPK Representative of Jawa Timur Province.

Transfer theories used in this study are: a) Siagian in Dewi (2017) which states that transfer serves to provide new experiences, expand the knowledge and skills of employees, avoid saturation, to fill existing vacancies, and increase the motivation of employees. b) Hasibuan (2016) which states that the purpose of transfer among others is to increase productivity, put people in the right positions, increase employee knowledge, encourage career planning, and create a balance of organizational structures.

From these theories it can be seen that, the purpose of the organization in carrying out transfers is to improve performance productivity. In order to achieve these goals, transfers must be carried out with an appropriate and planned transfer system. It can be concluded that the right transfer system will affect the increasing performance of employees. 
Furthermore according to Mahmudi in Sayd et al. (2016), factors that can affect individual performance include system and context factors. The stem is a work environment established by the organization that includes the rules and policies that shape the working culture of the organization, including the transfer system. While the context is the internal and external environmental conditions of organization in the form of threats and opportunities. In this study, these theories are not proven.

Based on the analysis of further data, it is known that there are some respondents' answer data that do not comply with the existing theory that transfers have a positive and significant influence on employee performance. Some employees with average perception of transfer are low but have high performance or very high. Likewise, some employees with average perception of high transfer but it have low performance or very low. Further research on respondent data, it is known that employees with high performance also have high motivation despite the perception of transfer is low. It can be explained that although employees have a low assessment of transfers but high internal motivation so that the performance is also high. Similarly, employees with low performance also have work motivation, especially internal motivation that rendah despite the perception of transfer is high. This may be because as mentioned earlier that internal motivation is an innate motivation that cannot be influenced by external environments including management and organization. The policy of about transfer as one form of environment built by the organization does not have a concern for the motivation and performance of employees.

Based on the results of more in-depth interviews with officials related to Human Resource Management, it is known that the number of employees with a very productive age and relatively young resulted in high idealism and work ethic owned need. It is also known that BPK has basic values as idealism that should be applied in carrying out the work, namely the value of independence, integrity, and professionalism. So that despite the perception of low employee transfers, employees still have to work according to the demands of professionalism of work to produce good performance.

Maslow's theory in Purwanto (2017) states that human needs consist of 5 hierarchies of needs namely physiological needs, the need for security, social needs, the need for appreciation, and the need for selfactualization. Herzberg theory in Purwanto (2017) states that one's motivation is influenced by 2 conditions that encourage motivation and conditions that inhibit motivation. Alderfer theory in Dimyati (2018) states that motivation arises from 3 groups of needs namely existence, connection, and growth.
From the various theories can be concluded that people/employees are encouraged to make the most efforts with the aim to meet their needs. This maximum effort will then result in improved individual performance. It can be said that work motivation greatly affects the performance of individuals. In this study, the theory was proven based on the results of regression analysis that showed that there is a significant impact between work motivations to employee performance in BPK Representative of Jawa Timur Province.

From the test results it is known that transfers and motivations simultaneously significantly affect the performance of employees in BPK Representative of Jawa Timur Province. This means that if the transfer system is good and the employee's motivation is higher, then the performance will be better and vice versa if the transfer system is low and the employee motivation is low then the performance will decrease.

Although the results of thenelitian variable transfer of employees do not significantly affect the performance, but together the transfer variables and work motivation significantly affect the performance of employees. This shows that the variable motivation of me work has a huge influence on employee performance.

\section{Conclusion}

Based on the test results on the analysis of the effect of transfers and work motivation on the performance of employees in BPK Representative of Jawa Timur Province, it can be concluded as follows:

Transfers implemented within the Financial Examiner's Board have not been fully based on merit system. Employee perception of transfer indicates that the transfer implemented has not used scientific considerations and is not based on the performance that has been achieved. Employees at BPK Representative of Jawa Timur Province feel that the policy of employee transfer within the Audit Board has not been clearly established and the lack of transparency and consistency gives the impression that the existing transfers have not been implemented objectively and scientifically.

The motivation owned by BPK Representative of Jawa Timur employees is high. It can be concluded that BPK Jawa Timur is able to increase employee motivation through external factors such as incentives, a harmonious work environment, and the prohibition given.

The performance of employees in BPK Representative of Jawa Timur province is high indicated by the high commitment, independence, effectiveness, 
timeliness, quantity, and quality of work of BPK Representatives of Jawa Timur.

The employee transfer has no significant effect on the performance of employees in BPK Representative of Jawa Timur Province. This is due to the presence of builtin factors that affect performance and motivation.

The motivation of uh work is positive and significant to the performance of employees at BPK Representative of Jawa Timur Province. If an employee's motivation is getting higher, then the performance will be better and vice versa if an employee's motivation is low then his performance will decrease.

Transfer and motivation of work simultaneously significantly affect the performance of employees in BPK Representative of Jawa Timur Province. If the transfer system is good and the employee's motivation is higher, then the performance will be better and more so if the transfer system is low and the employee motivation is low then the performance will decrease.

\section{Suggestion}

Suggestions that can be given based on this research are: For BPK RI to further improve the quality of employee transfer, especially in terms of implementing policy implementation as stipulated in Government Regulation No. 11 of 2017 concerning Civil Servant Management. In addition, BPK RI in order to improve regulations/standards regarding the mechanism of employee transfer in the internal environment of BPK based on the system and then conduct continuous socialization about the mechanism.

For BPK Representative of Jawa Timur Province to always monitor and increase the motivation of work owned by its employees. Improving employee motivation closely with the fulfillment of employee needs. Some of the efforts that can be made by the organization to increase employee motivation include providing incentives, creating a comfortable work environment, creating harmonious relationships between pegawai, encouraging good teamwork, and rewarding achievements achieved by employees.

For BPK Representative of Jawa Timur Province to always maintain and improve the performance owned by its employees. To be able to improve employee performance some things that can be done by the organization, among others, are improving employee competence through education and training, improving employee job satisfaction, or by creating a competitive work climate by rewarding and punishment.
For further research can deepen research on employee transfer variables considering in this study employee transfer variables have not proven significant effect on employee performance. For further research can deepen the research on variables that affect work motivation because in this study work motivation variables have a very significant influence on employee performance. For further researchers can conduct research on other variables that affect employee performance in addition to considering that there are still $14.1 \%$ (100\%$85.9 \%$ ), other variables that affect employee performance.

\section{References}

[1] Astuti. (2017). Analysis of Employee Work Activity M In An Effort to Improve Employee Work Productivity Case Study Of Metal Button Company Assembling Parts. Bandung: Pasundan University Bandung.

[2] Budiman, Arif (2018). Employee Transfer: a Review of Recent Literature. Journal of Public Administration Studies. JPAS Vol. 3 No. 1, pp 33-36, 2018. ISSN: 2548-902X.

[3] Dewi, J.P. (2017). Effect of Transfer and Motivation on Employee Performance of PT. Buana Samudra Lestari. Bekasi: Pelita Bangsa College of Economics.

[4] Dimyati, A. (2018). Effect of Transfer on Employee Motivation in Housing Office of Residential Area and Water Resource Management of Lampung Province (Research). Downloaded April 19, 2019 from World Wide Web: http://docplayer.info

[5] Hasibuan, M.S.P. (2016) Human Resource Management. Revised Edition. Jakarta: Bumi Aksara. Mangkunegara, A.P. (2017). Corporate Human Resource Management. Fourteenth Printing. Bandung: PT. Teen Rosda Works.

[6] Panggabean, M. S. (2016). Human Resource Management. Issue 2. Third Printing. Tangerang: Open University.

[7] Prasetya,Arik (2018). Analysis of Factors that Influence Employee Performance (Study on Permanent Employees in Operationel Section of PT WIMCycle Indonesia-Surabaya). Journal of Profit Volume 12 No. 1. 2018.

[8] Princess, G.F. (2016). Effect of Work Transfer on Operational Employee Performance at Vio Cihampelas Hotel Bandung. Bandung: Bandung College of Tourism. September 3, 2019

[9] Purwanto, Agus J., Elu, Wilfridus B. (2017). Innovation and Organizational Change. Second Edition. First Printing. South Tangerang:Unversitas Open.

[10] Republic Indonesia. Government Regulation No. 11 of 2017 concerning Civil Servant Management.

[11] Sari, D. (2015). The Influence of Job Satisfaction and Organizational Commitment to Employee Performance at PT. PUSKOPKAR Riau Pekanbaru. JOM FEKON Vol. No. February 101-1055.

[12] Sayd. G.A., etal. (2016). Journal of Factors Affecting the Quality of Performance of Rote Ndao Land Office. Journal of Social and Political Sciences 19(3), March 2016 (264-274). ISSN 1410-4946.

[13] Sutrisno,Edy. (2016). Human Resource Management. Eighth Printing. Jakarta: Kencana Prenada Media Group.

[14] Wildan, M.A. (2021). Macroeconomic Factors Affecting Natural Gas Export Management. International Journal of Energy Economics and Policy, 2021, 11(1), 639-644.

[15] Wildan, M.A. (2021). Work Motivation and Supervisor Performance in Indonesia. International Journal of Management Research and Social Science (IJMRSS), 8(2), April - June 2021.

[16] Wutsqo, W. U. (2017). Effect of Transfer and Incentive on Employee Performance (CaseStudy at The Office of Foreign Investment Tax Service Lima Jakarta). Yogyakarta: State University of Yogyakarta. Retrieved July 3, 2021 from World Wide Web: https://eprints.uny.ac.id 